\title{
Isolation and Structures of Novel Fungal Metabolites as Chemokine Receptor (CCR2) Antagonists
}

\author{
Kithsiri B. Herath, Hiranthi Jayasuriya, John G. Ondeyka, Jon D. Polishook, \\ Gerald F. Bills, Anne W. Dombrowski, Angeles Cabello, Pasquale P. Vicario, \\ Hans Zweerink, Ziqiang Guan, Sheo B. Singh
}

Received: September 20, 2005 / Accepted: October 21, 2005

(C) Japan Antibiotics Research Association

\begin{abstract}
The chemokine receptor, CCR2, is predominantly expressed on monocytes/macrophages, and on a subset of memory $\mathrm{T}$ cells. It binds to several $\mathrm{CC}$ type chemokines of the monocyte chemoattractant protein (MCP) family of which MCP-1 exhibits the highest affinity. CCR2/MCP-1 expression/association in monocyte/macrophage/T cells has been associated with inflammatory processes such as rheumatoid arthritis, multiple sclerosis and atherosclerosis. Neutralization of CCR2 with either a peptide or receptor antagonist results in the prevention of joint swelling in rodent models of arthritis. In this paper, bioassay-guided discovery of CCR2 receptor antagonists derived from natural product extracts are reported. These antagonists belong to two main classes exemplified by bisthiodiketopiperazines and cytochalasins. Six compounds, including emestrin, two new emestrin analogs, and chaetomin represent the first group of compounds. These compounds inhibited the binding of MCP-1 to CCR2 (CHO membrane) with $\mathrm{IC}_{50}$ values of 0.8 to $9 \mu \mathrm{M}$ and exhibited good activity in a whole cell assay using MCP-1 and human monocytes with $\mathrm{IC}_{50 \text { 's }}$ ranging from $4 \sim 9 \mu \mathrm{M}$. Cytochalasins A and $\mathrm{B}$ represented the second group and inhibited the binding activity with $\mathrm{IC}_{50}$ values of 5 and $188 \mu \mathrm{M}$, respectively. This is the first report of natural product antagonists of the $\mathrm{CCR} 2$ receptor.
\end{abstract}

Keywords CCR2 antagonists, natural products, bisthioketopiperazines, microbial products

\section{Introduction}

Chemokines regulate leukocyte development and chemotaxis, and play an important role in their trafficking through the vascular and lymphatic systems. Monocyte chemoattractant protein-1 (MCP-1, CCL2), one of the first chemokines discovered, binds with high affinity and selectivity to the CCR2 receptor and this interaction appears to regulate inflammation in the lung and several other organs. The MCP-1-CCR2 complex is also associated with a number of other disease targets such as autoimmune disorders including rheumatoid arthritis, atherosclerosis, and infectious diseases. The biological significance of MCP-1/CCR2 association in these systems has been recently reviewed [1 5]. Neutralization of CCR2 with either a peptide or small molecule receptor antagonist results in the suppression or prevention of joint swelling in rodent models of rheumatoid arthritis [6,7]. Our expectation is that a small molecule non-peptide antagonist of the MCP-1 binding to CCR2 may have a beneficial therapeutic effect against many of these disease targets.
S. B. Singh (Corresponding author), K. B. Herath, H. Jayasuriya, J. G. Ondeyka, J. D. Polishook, A. W. Dombrowski, P. P. Vicario, H. Zweerink, Z. Guan: Merck Research Laboratories, P.O. Box 2000, Rahway, NJ 07065, U.S.A. E-mail: sheo_singh@merck.com
G. F. Bills, A. Cabello: CIBE, Merck Sharp \& Dohme de Espania, S. A. Josefa Valcarcel 38, 28027 Madrid, Spain 
We screened a library of natural product extracts derived from microbial fermentations and plants using a filterbinding assay utilizing ${ }^{125} \mathrm{I}-\mathrm{MCP}-1$ and $\mathrm{CHO}$ membranes leading to four hits, all of microbial origin. Bioassay guided fractionation of three of the extracts led to the discovery of a number of compounds dominated by bisthiodiketopiperazines. These include compounds of the emestrin family including emestrin (1), emestrin $\mathrm{C}$ (MPC1001, 2), emestrin D (MPC1001D, 3), two new members named herein as emestrin $E(4)$, secoemestrin $C_{1}$ (5), and chaetomin (6) (Figure 1). Similar fractionation of the fourth extract led to the isolation of cytochalasins A (7) and $\mathrm{B}(\mathbf{8})$, the only compounds isolated in this program that did not contain the bis-thiodiketopiperazine unit. The isolation, structure elucidation and biological activities of these compounds are described.

\section{Results and Discussion}

\section{Emestrin (1)}

Emestrin (1) was produced by Verticimonosporium ellipticus isolated from leaf litter collected in Puerto Rico and grown on a solid fermentation medium. The mycelia were extracted with methyl ethyl ketone and the extract triturated with $\mathrm{CH}_{2} \mathrm{Cl}_{2}$ and $\mathrm{MeOH}$. Sephadex $\mathrm{LH} 20$ chromatography of the $\mathrm{CH}_{2} \mathrm{Cl}_{2}$ soluble material afforded $7 \mathrm{mg} /$ liter of emestrin (1). It was characterized by comparison of ${ }^{1} \mathrm{H},{ }^{13} \mathrm{C}$ NMR and optical rotation to that of emestrin reported from Emericella striata $[8,9]$.

\section{Emestrins $C \sim E(2 \sim 4)$ and Secoemestrin $C_{1}(5)$}

Compounds $\mathbf{2} \sim \mathbf{5}$ were produced by the sterile mycelium of

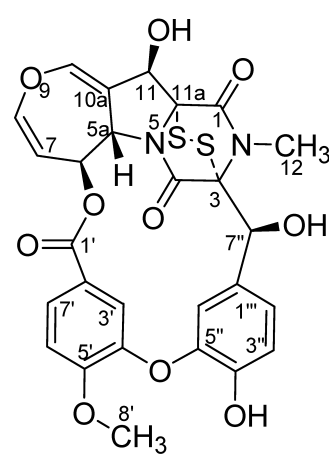

1 (Emestrin)

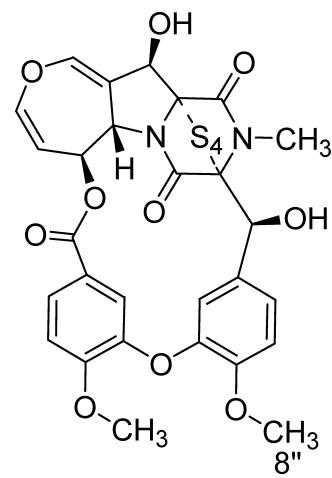

4 (Emestrin $\mathrm{E}$ )

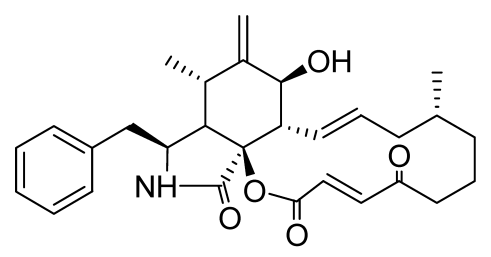

7 (Cytochalasin A)

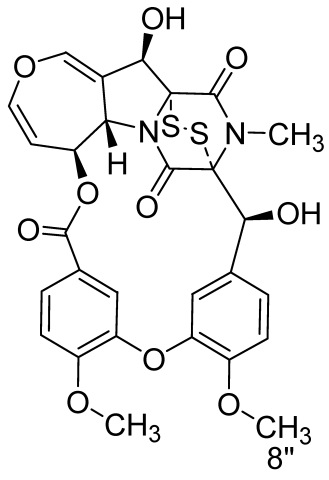

2 (Emestrin C)<smiles></smiles>

5 (Secoemestrin $\mathrm{C}_{1}$ )

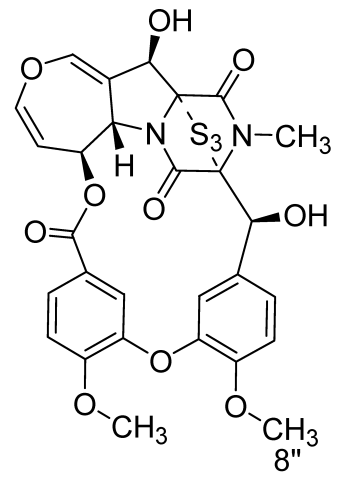

3 (Emestrin D)

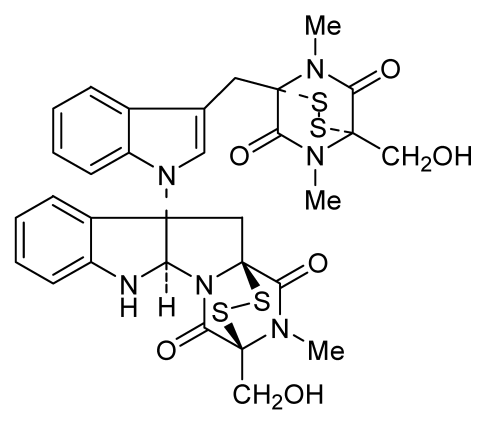

6 (Chaetomin)

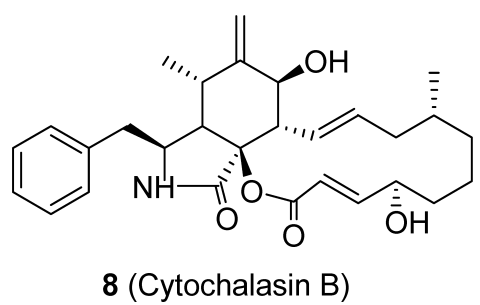

Fig. 1 The structures of compounds $\mathbf{1} \sim \mathbf{8}$. 
a fungus isolated from Musk Ox dung collected from Alaska and grown in a liquid medium. The fermentation was extracted with methyl ethyl ketone. Gel permeation chromatography of the extract followed by reverse phase and diol HPLC (Figure 2) furnished $2(0.4 \mathrm{mg} /$ liter $), 3$ (1.4 $\mathrm{mg} /$ liter $), 4$ (0.2 $\mathrm{mg} /$ liter), and 5 ( $1 \mathrm{mg} /$ liter $)$.

\section{Emestrin C (2)}

HRESIMS analysis of $\mathbf{2}$ produced a molecular formula $\mathrm{C}_{28} \mathrm{H}_{24} \mathrm{~N}_{2} \mathrm{O}_{10} \mathrm{~S}_{2}$ (MW 612) that was equivalent to one methylene unit more than emestrin $\left(\mathrm{C}_{34} \mathrm{H}_{16} \mathrm{~N}_{2} \mathrm{O}_{4} \mathrm{~S}_{2}\right.$, MW 598). The UV spectrum of 2 was identical to that of emestrin. The ${ }^{1} \mathrm{H}$ NMR spectrum (Table 1) of $\mathbf{2}$ was identical to the spectrum of emestrin except for the presence of an additional aromatic methoxy group appearing at $\delta_{\mathrm{H}} 3.97$ that was assigned to the new methoxy group at C-4". When ${ }^{1} \mathrm{H}$ NMR spectrum of $\mathbf{2}$ was recorded in a dilute solution of $\mathrm{CDCl}_{3}(<1 \mathrm{mM})$ the signal for $\mathrm{OH}-7^{\prime \prime}$ consistently appeared as a doublet at $\delta_{\mathrm{H}} 4.77(J=12.5 \mathrm{~Hz})$ and showed a coupling to H-7" $\left(\delta_{\mathrm{H}} 5.45, \mathrm{~d}, J=12 \mathrm{~Hz}\right)$ most likely due to six centered hydrogen bonding between $\mathrm{OH}$ proton and the keto group. However, at increased concentration $(>2 \mathrm{mM})$ the signal broadened and the coupling to H-7" was not observed and consequently it appeared as a singlet at $\delta_{\mathrm{H}} 5.45$ due to diffusion of hydrogen bonding.

Methylation of emestrin (1) with diazomethane overnight at $-10^{\circ} \mathrm{C}$ afforded methyl-emestrin which was shown to be identical to $\mathbf{2}$ by direct comparison of HPLC, ${ }^{1} \mathrm{H}$ NMR and specific rotation data. Therefore, emestrin $\mathrm{C}$ was elucidated as C-4"-methoxy emestrin (2).

\section{Emestrin D (3)}

HRESIMS of $\mathbf{3}$ provided a molecular formula $\mathrm{C}_{28} \mathrm{H}_{24} \mathrm{~N}_{2} \mathrm{O}_{10} \mathrm{~S}_{3}$ (MW 644) and suggested to have an additional sulfur atom in comparison to 2 . The ${ }^{1} \mathrm{H}$ and ${ }^{13} \mathrm{C}$ NMR spectra (Table 1) of $\mathbf{3}$ was similar to the spectra of $\mathbf{1}$ and 2, and were completely assigned from 2D COSY, HMQC and HMBC data (Table 1). The HRESIMS fragmentation of both emestrins $\mathrm{C}(\mathbf{2})$ and $\mathrm{D}(\mathbf{3})$ produced a common fragment ion at $\mathrm{m} / \mathrm{z} 531$ due to the loss of a molecule of water and sulfur atoms and confirmed the presence of the additional sulfur atom in $\mathbf{3}$ compared to $\mathbf{2}$. Thus, the structure 3 with three sulfur atoms bridging C3C11a was assigned to emestrin D which is 4 "-methoxy emestrin B [10]. While this study was in progress compounds 2 and $\mathbf{3}$ named as MPC1001 and MPC1001D, respectively, were reported from Cladorrhinum sp. as antiproliferative agent with $\mathrm{IC}_{50}$ value of 9.3 and $16 \mathrm{nM}$, respectively, against DU145 human prostate cancer cell line [11].

\section{Emestrin E (4)}

The molecular formula of $4\left(\mathrm{C}_{28} \mathrm{H}_{24} \mathrm{~N}_{2} \mathrm{O}_{10} \mathrm{~S}_{4}\right)$ indicated the presence of another sulfur atom when compared to emestrin $\mathrm{D}$, which was likewise assigned to the C3-C11a

Fungal fermentation

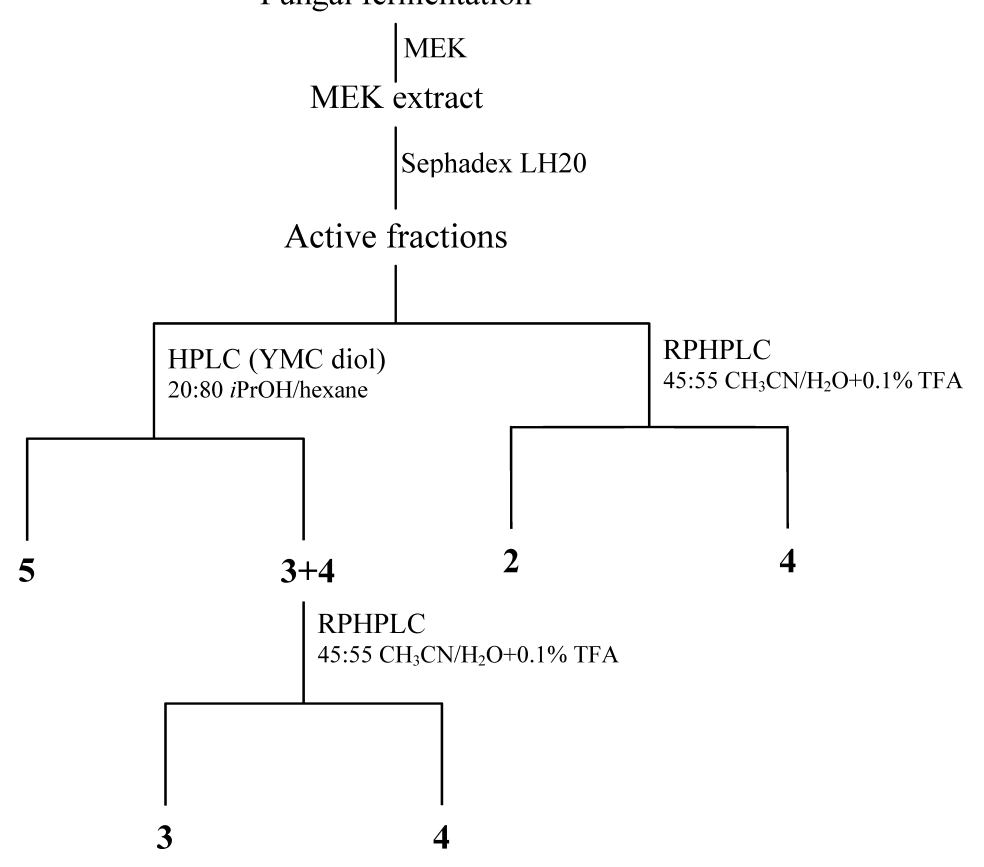

Fig. 2 Isolation of emestrins $C \sim E(\mathbf{2} \sim \mathbf{4})$ and secoemestrin $C_{1}(\mathbf{5})$. 
Table 1 NMR assignments of emestrins $C \sim E(\mathbf{2} \sim \mathbf{4})$ and secoemestrin $C_{1}(\mathbf{5})$ in $\mathrm{CDCl}_{3}$

\begin{tabular}{|c|c|c|c|c|c|c|c|}
\hline \multirow[b]{2}{*}{ Position } & \multicolumn{3}{|c|}{3} & \multirow{2}{*}{$\frac{2}{\delta_{\mathrm{H}}, \text { mult. } J \text { in } \mathrm{Hz}}$} & \multirow{2}{*}{$\frac{4}{\delta_{\mathrm{H}}, \text { mult. } J \text { in } \mathrm{Hz}}$} & \multicolumn{2}{|r|}{5} \\
\hline & $\delta_{\mathrm{C}}$ & $\delta_{\mathrm{H}}$, mult. $J$ in $\mathrm{Hz}$ & $\mathrm{HMBC}(\mathrm{H} \rightarrow \mathrm{C})$ & & & $\delta_{\mathrm{C}}$ & $\delta_{\mathrm{H}}$, mult. $J$ in $\mathrm{Hz}$ \\
\hline 1 & 168.0 & - & $\mathrm{H}-11$ & - & - & 166.1 & - \\
\hline 3 & 77.9 & - & $\mathrm{H}-11$ & - & - & 78.3 & - \\
\hline 4 & 165.2 & - & & - & - & 162.2 & - \\
\hline $5 a$ & 58.9 & $5.41, \mathrm{dd}, 8.0,2.0$ & $\mathrm{H}-6,7,10,11$ & $5.93, \mathrm{dd}, 7.5,2.0$ & $5.69, \mathrm{dd}, 8.0,2.0$ & 63.0 & 5.32, br d, 8.0 \\
\hline 6 & 74.8 & $5.29, \mathrm{dt}, 8.0,2.0$ & $\mathrm{H}-5 \mathrm{a}, 7,8$ & $4.82, \mathrm{dt}, 7.5,2.0$ & $5.23, \mathrm{dt}, 8.0,2.0$ & 70.4 & $5.83, \mathrm{dt}, 8.4,2.0$ \\
\hline 7 & 109.9 & $5.05, \mathrm{dd}, 8.0,2.0$ & $\mathrm{H}-8$ & $4.98, d d, 8.5,2.0$ & $5.00, \mathrm{dd}, 8.0,2.0$ & 105.8 & $4.68, \mathrm{dd}, 8.0,2.0$ \\
\hline 8 & 138.5 & $6.37, \mathrm{dd}, 8.0,2.0$ & $\mathrm{H}-7,10$ & $6.34, \mathrm{dd}, 8.5,2.0$ & $6.35, \mathrm{dd}, 8.0,2.0$ & 141.1 & $6.31, \mathrm{dd}, 8.0,2.0$ \\
\hline 10 & 142.9 & $6.85, d, 2.0$ & $\mathrm{H}-5 \mathrm{a}, 8,11$ & $6.93, d, 2.0$ & $6.86, d, 2.0$ & 139.4 & 6.67, br d, 2.0 \\
\hline $10 a$ & 107.8 & - & $\mathrm{H}-5 \mathrm{a}, 10$ & - & - & 113.4 & - \\
\hline 11 & 79.7 & $4.81, \mathrm{~s}$ & $\mathrm{H}-10$ & 4.95, br s & $4.91, \mathrm{~s}$ & 35.3 & $\begin{array}{l}4.14, \text { br d, } 18 \\
3.16, \text { br d, } 18\end{array}$ \\
\hline $11 a$ & 83.0 & - & $\mathrm{H}-5 \mathrm{a}, 11$ & - & - & 73.4 & - \\
\hline 12 & 28.8 & $3.58, \mathrm{~s}$ & & $3.43, \mathrm{~s}$ & $3.27, \mathrm{~s}$ & 29.4 & $2.95, \mathrm{~s}$ \\
\hline $1^{\prime}$ & 166.3 & - & $\mathrm{H}-3^{\prime}, 7^{\prime}$ & - & - & 165.4 & - \\
\hline $2^{\prime}$ & 122.2 & - & $\mathrm{H}-3^{\prime}, 6^{\prime}$ & - & - & 121.4 & - \\
\hline $3^{\prime}$ & 119.4 & $8.05, d, 2.0$ & $\mathrm{H}-7^{\prime}$ & $7.66, d, 2.0$ & $8.25, d, 2.0$ & 116.6 & $7.60, d, 2.0$ \\
\hline $4^{\prime}$ & 146.2 & - & $\mathrm{H}-3^{\prime}, 6^{\prime}$ & - & - & 143.0 & - \\
\hline $5^{\prime}$ & 154.6 & - & $\mathrm{H}-3^{\prime}, 6^{\prime}, 7^{\prime}, 8^{\prime}$ & - & - & 149.3 & - \\
\hline $6^{\prime}$ & 112.1 & $7.04, d, 8.5$ & & $7.06, d, 8.5$ & $7.09, d, 8.5$ & 114.6 & $6.93 d, 8.8$ \\
\hline $7^{\prime}$ & 125.8 & $7.75, \mathrm{dd}, 8.5,2.0$ & $\mathrm{H}-3^{\prime}, 6^{\prime}$ & $7.78, \mathrm{dd}, 8.5,2.0$ & $7.84, \mathrm{dd}, 8.5,2.0$ & 124.3 & $7.61, \mathrm{dd}, 8.8,2.0$ \\
\hline $8^{\prime}$ & 56.3 & $4.06, \mathrm{~s}$ & & $4.02, \mathrm{~s}$ & $4.06, \mathrm{~s}$ & - & - \\
\hline $1^{\prime \prime}$ & 126.9 & - & & - & - & 133.7 & - \\
\hline $2^{\prime \prime}$ & 128.6 & $7.05, \mathrm{dd}, 8.5,2.0$ & $\mathrm{H}-6^{\prime \prime}$ & $7.13, \mathrm{dd}, 8.0,2.0$ & $7.21, \mathrm{dd}, 8.5,2.0$ & 128.5 & $7.15 \sim 7.20$ \\
\hline $3^{\prime \prime}$ & 110.6 & $6.86, d, 8.5$ & & $6.95, d, 8.0$ & $6.96, d, 8.5$ & 129.2 & $7.15 \sim 7.20$ \\
\hline $4^{\prime \prime}$ & 152.1 & - & $\mathrm{H}-2^{\prime \prime}, 3^{\prime \prime}, 6^{\prime \prime}, 8^{\prime \prime}$ & - & - & 127.4 & $7.15 \sim 7.20$ \\
\hline $5^{\prime \prime}$ & 145.5 & - & H-3", 6" & - & - & 129.2 & $7.15 \sim 7.20$ \\
\hline $6^{\prime \prime}$ & 125.5 & $8.30, d, 2.0$ & $\mathrm{H}-2^{\prime \prime}$ & $7.68, d, 2.5$ & $8.43, d, 2.5$ & 128.5 & $7.15 \sim 7.20$ \\
\hline $7^{\prime \prime}$ & 76.4 & 5.31, br s & H-2", 6" & $5.45, d, 12.0$ & 5.37, br s & 36.2 & $\begin{array}{l}3.68, d, 16 \\
3.63, d, 16\end{array}$ \\
\hline $\begin{array}{l}8^{\prime \prime} \\
7 "-\mathrm{OH}\end{array}$ & 56.0 & $3.87, \mathrm{~s}$ & & $\begin{array}{l}3.97, \mathrm{~s} \\
4.77, \mathrm{~d}, 12.5\end{array}$ & $3.97, \mathrm{~s}$ & - & - \\
\hline $11-\mathrm{OH}$ & & & & $5.23, \mathrm{~s}$ & & & \\
\hline
\end{tabular}

bridge, and was confirmed by the presence of the fragment ion at $m / z$ 531. The structure of 4 was corroborated by ${ }^{1} \mathrm{H}$ and ${ }^{13} \mathrm{C}$ NMR spectral data (Table 1) comparison with the data of $\mathbf{2}$ and $\mathbf{3}$.

\section{Secoemestrin $\mathbf{C}_{\mathbf{1}}$ (5)}

HRESIMS analysis of $\mathbf{5}$ afforded a molecular formula $\mathrm{C}_{26} \mathrm{H}_{22} \mathrm{~N}_{2} \mathrm{O}_{7} \mathrm{~S}_{2}$ (MW 538) indicating the presence of two sulfur atoms in the molecule like in emestrin $\mathrm{C}$ (2). Comparison of the ${ }^{1} \mathrm{H}$ NMR spectra (Table 1) of 5 with 2 showed the absence of both methoxy groups and H-11 and $\mathrm{H}-\mathrm{7}^{\prime \prime}$ oxymethines, and the presence of a monosubstituted phenyl group indicating the opening of the macrocycle. The
${ }^{1} \mathrm{H}$ and ${ }^{13} \mathrm{C}$ NMR spectra were assigned from COSY, HMQC and HMBC data and are listed in Table 1.

ESIMS fragmentation (Figure 3) of $\mathbf{5}$ produced a major fragment ion at $m / z 385(80 \%)$, that was attributed to the facile loss of the dihydroxybenzoic acid unit which, after elimination of $\mathrm{HS}_{2}$, produced a stable fragment ion at $\mathrm{m} / \mathrm{z}$ 320. The ESIMS fragmentation pattern of secoemestrin $C_{1}$ differed significantly from the macrocycle-containing compounds $\mathbf{1} \sim \mathbf{4}$ in which only a loss of water are observed. Based on these data structure $\mathbf{5}$ was assigned to secoemestrin $C_{1}$. 


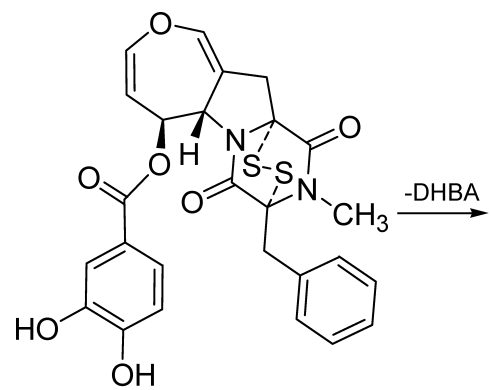

$m / z 556(\mathrm{M}+\mathrm{NH} 4]$

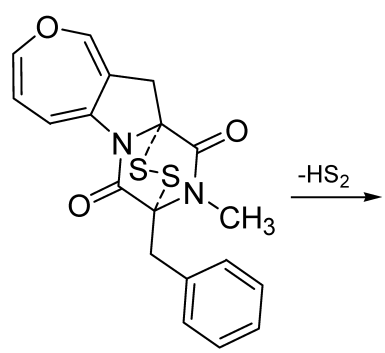

$m / z 385[+\mathrm{H}]$

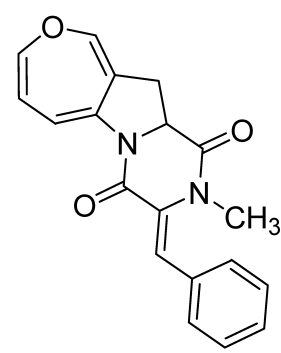

$m / z 320$

Fig. 3 ESIMS fragmentation of secoemestrin $C_{1}(\mathbf{5})$.

\section{Chaetomin (6)}

Sterile mycelia was isolated from a soil sample collected in Argentina and grown on a liquid medium which was extracted by MEK and chromatographed on reverse phase HPLC affording $77 \mathrm{mg} /$ liter of chaetomin (6). The structure was confirmed by comparison of ${ }^{1} \mathrm{H},{ }^{13} \mathrm{C}$ NMR spectra and specific rotation of chaetomin that is reported to be a toxic bacteriostatic agent [12].

\section{Cytochalasins A (7) and B (8)}

These were produced by sterile mycelia isolated from decaying leaves collected in Costa Rica. Gel permeation chromatography of the MEK extract over Sephadex LH 20 followed by reversed phase HPLC led to the isolation of cytochalasins A (7, $40 \mathrm{mg} /$ liter) and B (8, $120 \mathrm{mg} /$ liter $)$ whose structures were elucidated by comparison of spectral data (UV, ${ }^{1} \mathrm{H}$, and ${ }^{13} \mathrm{C}$ NMR) [12], with authentic samples.

\section{Biological Activity}

All compounds were first evaluated for their activity in the $\mathrm{CCR} 2$ membrane binding assay using $\mathrm{CCR} 2$ receptor $\mathrm{CHO}$ cell membrane and ${ }^{125} \mathrm{I}-\mathrm{MCP}$. The results of this assay are presented in Table 2. Emestrins $(\mathbf{1} \sim \mathbf{3})$ each with two to three sulfur atoms, and with or without a free phenolic group, exhibited $\left(\mathrm{IC}_{50} \sim 0.8 \mu \mathrm{M}\right.$ ) equal activities in this assay. However, compound $\mathbf{4}$ with four-sulfur atoms was slightly less active $\left(\mathrm{IC}_{50}=1.1 \mu \mathrm{M}\right)$. Secoemestrin $\mathrm{C}_{1}$ (5) exhibited $\mathrm{IC}_{50}=9.3 \mu \mathrm{M}$ and was ten times less active than $\mathbf{1}$ indicating the importance of the macrocycle for binding activity. Chaetomin (6) showed intermediate activity between $\mathbf{1}$ and $\mathbf{5}$ and exhibited an $\mathrm{IC}_{50}$ value of $5.07 \mu \mathrm{M}$. The binding activities of cytochalasins A (7) and B (8) were dramatically different, $\mathrm{IC}_{50}$ values being 5.24 and 188 $\mu \mathrm{M}$, respectively, showing the importance of the enone moiety of 7 for the activity when compared to enol moiety of 8. In a similar MIP- $1 \alpha$ membrane binding CCR5 assay, chaetomin showed $\mathrm{IC}_{50}$ of $28 \mu \mathrm{M}$ and exhibited approximately 6 fold selectivity for CCR2 receptor.
Table 2 Inhibition of ${ }^{125}$ /-MCP-1 binding to CCR2 receptor by fungal metabolites (1 $\sim \mathbf{8})$

\begin{tabular}{crc}
\hline & $\begin{array}{c}\text { Membrane } \\
140 \mathrm{LCCR} 2 / \mathrm{CHO} \\
\mathrm{I} \mathrm{C}_{50}(\mu \mathrm{M})\end{array}$ & $\begin{array}{c}\text { Whole cell } \\
\text { Human monocyte CCR2 } \\
\mathrm{IC}_{50}(\mu \mathrm{M})\end{array}$ \\
\hline $\mathbf{1}$ & $0.84 \pm 0.3$ & $5.4 \pm 0.7$ \\
$\mathbf{2}$ & $0.82 \pm 0.4$ & $4.1 \pm 0.7$ \\
$\mathbf{3}$ & $0.78 \pm 0.4$ & $4.2 \pm 0.4$ \\
$\mathbf{4}$ & $1.10 \pm 0.5$ & $\mathrm{NA}$ at $10 \mu \mathrm{M}$ \\
$\mathbf{5}$ & $9.30 \pm 1.2$ & $7.9 \pm 1.0$ \\
$\mathbf{6}$ & $5.07 \pm 1.2$ & $9.5 \pm 2.9$ \\
$\mathbf{7}$ & $5.24 \pm 1.3$ & $\mathrm{NA}$ at $10 \mu \mathrm{M}$ \\
$\mathbf{8}$ & $188.00 \pm 15$ & $\mathrm{NA}$ at $10 \mu \mathrm{M}$ \\
\hline
\end{tabular}

NA: not active.

These compounds were also evaluated in a whole cell assay using human monocyte cells harvested from Leukopacks. Emestrins 1 $\mathbf{3}$ inhibited the ${ }^{125} \mathrm{I}-\mathrm{hMCP}-1$ binding to CCR2 receptor in these cells with $\mathrm{IC}_{50}$ values of 5.4, 4.1 and $4.2 \mu \mathrm{M}$, respectively, and were amongst the better actives of the series of molecules tested. The activity exhibited by these compounds in this assay was $5 \sim 8$ fold lower than the results obtained in the membrane binding assay. Emestrin E (4) with four sulfur atoms was significantly less active in the cell based assay $\left(\mathrm{IC}_{50} \gg 10\right.$ $\mu \mathrm{M})$ compared to the membrane binding assay. Secoemestrin $\mathrm{C}_{1}$ exhibited an $\mathrm{IC}_{50}$ of $7.9 \mu \mathrm{M}$ in the cell based assay which was similar to the membrane binding activity. The whole cell activity of secoemestrin $\mathrm{C}_{1}$ was about two fold lower than macrocyclic emestrins $1 \sim 3$. The whole cell activity exhibited by chaetomin was two fold lower than the membrane binding activity $\left(\mathrm{IC}_{50} 9.05\right.$ versus $5.07 \mu \mathrm{M})$. Neither of the cytochalasins exhibited any whole cell inhibitory activity at $10 \mu \mathrm{M}$ and were not evaluated further. 

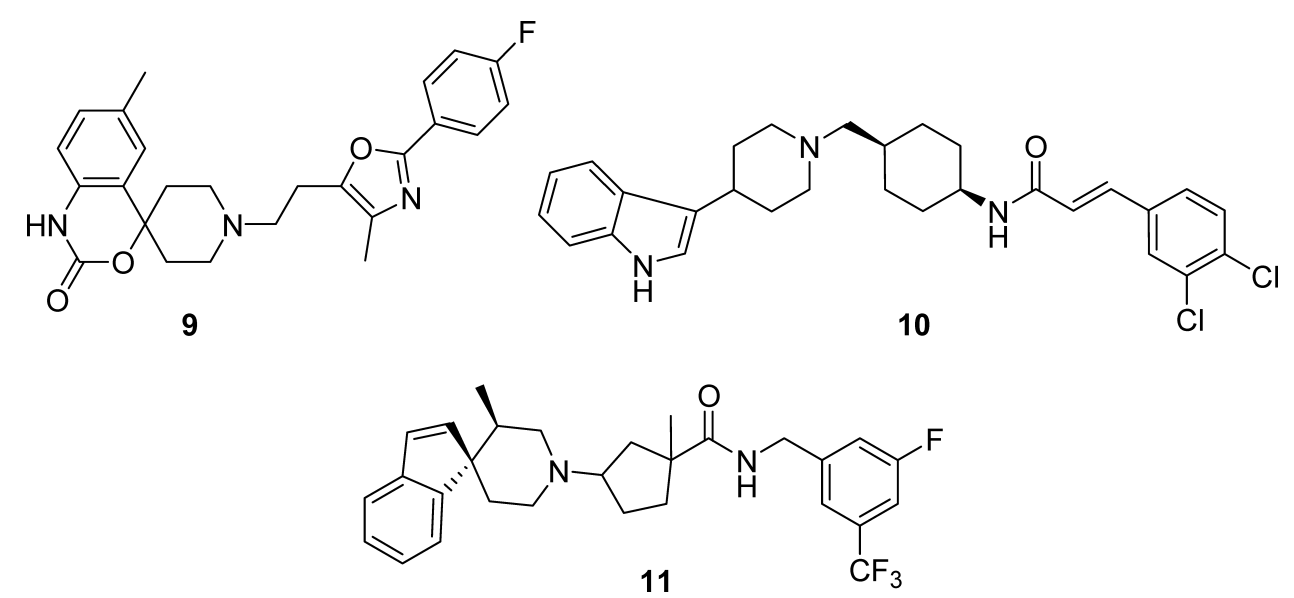

Fig. 4 Structures of compounds $\mathbf{9} \sim \mathbf{1 1}$.

Emestrin has been reported to induce DNA fragmentation [13], and causes acute poisoning in mice $\left(\mathrm{LD}_{50}\right.$ $13 \mathrm{mg} / \mathrm{kg}$ ) [14]. Cytochalasins are known for a variety of biological activities. For example, they effect phagocytosis [15], inhibit glucose transport [16 18], inhibit HIV-1 protease [19], and antagonize the monocyte-CCR5 receptor [20].

In summary, we have reported here a number of known and new bis-thiodiketopiperazines and cytochalasins as antagonists of the CCR2 receptor. Although a number of synthetic (exemplified by compounds 9 [5], 10 [21] and 11 [22], Figure 4) potent (nM) antagonists of the CCR2 receptor have been reported in patent literature, these compounds constitute the first report of natural product antagonists.

\section{Experimental}

\section{General Procedure}

All biological material was collected in strict accordance with the Rio Convention on Biodiversity. All reagents were purchased from Sigma-Aldrich (cat \# listed) or otherwise listed. NMR spectra were recorded on Varian Inova $500 \mathrm{MHz}$ instruments operating at $500 \mathrm{MHz}$ for ${ }^{1} \mathrm{H}$ and 125 $\mathrm{MHz}$ for ${ }^{13} \mathrm{C}$ nuclei. An HP1100 was used for analytical HPLC. LC-MS was performed on a Thermo Quest LCQ instrument using electrospray ionization (ESI) or atmospheric pressure chemical ionization (APCI). High resolution mass spectral analyses were performed on a Thermo Quest FTMS using electrospray ionization. For column chromatography silica gel H (E. Merck 60 200 mesh) was used.

The materials used for assays such as Bovine serum albumin Bovine (A-7030), polyethylenimine (P-3143, in $0.10 \%$ water), protease inhibitors cocktail (P-8340, stored at $-20^{\circ} \mathrm{C}$ ), bacitracin (B-0125), hMCP-1 (Peprotech, Rocky Hill, NJ), ${ }^{125} \mathrm{I}-\mathrm{hMCP}-1$ (New England Nuclear, NEX-332), BSA (30\% solution, Calbiochem \#126625), and microscint 0 (Packard) were obtained from the listed sources and used as received. Radioactivity was measured using Topcount NXT manufactured by Packard. Fermentation trace elements ( $\mathrm{g} /$ liter) are as follows: $\mathrm{FeSO}_{4} \cdot 7 \mathrm{H}_{2} \mathrm{O}(1), \mathrm{MnSO}_{4} \cdot \mathrm{H}_{2} \mathrm{O}(1), \mathrm{CuCl}_{2} \cdot 2 \mathrm{H}_{2} \mathrm{O}(0.025)$, $\mathrm{CaCl}_{2}(0.1), \mathrm{H}_{3} \mathrm{BO}_{3}$ (0.056), $\left(\mathrm{NH}_{4}\right)_{6} \mathrm{Mo}_{7} \mathrm{O}_{24} \cdot 7 \mathrm{H}_{2} \mathrm{O}(0.019)$, and $\mathrm{ZnSO}_{4} \cdot 7 \mathrm{H}_{2} \mathrm{O}(0.2)$, and were prepared in $0.6 \mathrm{~N} \mathrm{HCl}$.

\section{Fermentation and Isolation of Emestrin (1)}

Verticimonosporium ellipticus (MF6808, isolated from leaf litter collected in Puerto Rico), was inoculated into seed flasks by transferring an $1 \mathrm{ml}$ aliquot of a frozen culture into a $250 \mathrm{ml}$ unbaffled Erlenmeyer flask containing $50 \mathrm{ml}$ of NAS seed medium (in g/liter, corn steep powder 2.5; tomato paste 40 , oat flour 10 , glucose 10 , trace elements 10 $\mathrm{ml}, \mathrm{pH}$ 6.8). The seed culture was incubated at $25^{\circ} \mathrm{C}$ on a gyratory shaker $(220 \mathrm{rpm})$ for 3 days before transferring to $\mathrm{NPF} 2$ production medium (in $\mathrm{g} /$ liter of water, dextrose 150 ; urea 4; $\mathrm{NZ}$ amine type A 4.0; $\mathrm{K}_{2} \mathrm{HPO}_{4} 0.5, \mathrm{MgSO}_{4} \cdot 7 \mathrm{H}_{2} \mathrm{O}$ $0.25 ; \mathrm{KCl} 0.25 ; \mathrm{ZnSO}_{4} \cdot 7 \mathrm{H}_{2} \mathrm{O} 0.90 ; \mathrm{CaCO}_{3}$ 16.5). A $220 \mathrm{ml}$ of a liquid nutrient aliquot was added to $675 \mathrm{ml}$ of vermiculite in 2-liter roller bottles. A $10 \mathrm{ml}$ aliquot of the seed culture was added and shaken to coat the vermiculite. The inoculated roller bottles were incubated at $4 \mathrm{rpm}$ on a Wheaton rolling machine at $22^{\circ} \mathrm{C}$ for 18 days.

A 6 liters fermentation was extracted with 7.2 liters of methyl ethyl ketone. The organic extract was concentrated under reduced pressure to $100 \mathrm{ml}$ of mostly aqueous suspension which was extracted with $100 \mathrm{ml} \mathrm{CH}_{2} \mathrm{Cl}_{2}$. The 
$\mathrm{CH}_{2} \mathrm{Cl}_{2}$ extract that contained most of the emestrin was concentrated to give $3 \mathrm{~g}$ of oil that was chromatographed on a 2-liter Sephadex LH 20 column and eluted with $\mathrm{MeOH}$. Emestrin was highly retained and eluted after two column volumes of eluent. Concentration of the fractions under reduced pressure afforded $42 \mathrm{mg}$ ( $7 \mathrm{mg} /$ liter) of emestrin (1) as a colorless amorphous powder homogenous by HPLC [Rt=5.5 minutes, Zorbax XDB $(4.6 \times 150 \mathrm{~mm})$, $40 \sim 60, \mathrm{CH}_{3} \mathrm{CN}-\mathrm{H}_{2} \mathrm{O}+0.1 \%$ TFA, $1 \mathrm{ml} /$ minute $]$ and ${ }^{1} \mathrm{H}$ and ${ }^{13} \mathrm{C}$ NMR spectra.

\section{Methylation of Emestrin}

To a cooled $\left(-10^{\circ} \mathrm{C}\right)$ solution of emestrin $(7 \mathrm{mg})$ in a $1: 1$ mixture of $\mathrm{CH}_{2} \mathrm{Cl}_{2}$ and THF (1 ml) was added an excess of an ethereal solution of freshly prepared diazomethane. After stirring at $-10^{\circ} \mathrm{C}$ for 4 hours, the yellow solution was stored in a freezer overnight after which the volatile material was removed under a stream of nitrogen. The methylated product was purified by RPHPLC (Zorbax RX $\mathrm{C}-8,21 \times 250 \mathrm{~mm}, 45 \sim 55, \mathrm{CH}_{3} \mathrm{CN}-\mathrm{H}_{2} \mathrm{O}+0.1 \%$ TFA, flow rate $12 \mathrm{ml} /$ minute). Compound 2 eluted in fractions eluting in between 38 43 minute and were lyophilized to afford $3.5 \mathrm{mg}$ of 2 as a colorless amorphous powder. $[\alpha]_{\mathrm{D}}^{25}=87^{\circ}(c$ $0.4, \mathrm{MeOH})$.

\section{Fermentation and Isolation of Emestrins $C \sim E(2 \sim 4)$ and Secoemestrin $\mathrm{C}_{\mathbf{1}}(\mathbf{5})$}

Sterile mycelia (MF6822, isolated from Musk Ox dung collected from Alaska), was inoculated into seed flasks by transferring one $\mathrm{ml}$ aliquot of a frozen culture into a $250 \mathrm{ml}$ unbaffled Erlenmeyer flask containing $50 \mathrm{ml}$ of NAS seed medium. The seed culture was incubated at $25^{\circ} \mathrm{C}$ on a gyratory shaker $(220 \mathrm{rpm})$ for 4 days before transfer to NPGG liquid production medium (in g/liter, glycerol 75, glucose 75; tomato paste 5, NZ amine type A 4.0; $\mathrm{K}_{2} \mathrm{HPO}_{4}$ $0.5, \mathrm{MgSO}_{4} \cdot 7 \mathrm{H}_{2} \mathrm{O} \quad 0.25 ; \mathrm{KCl} 0.25 ; \mathrm{ZnSO}_{4} \cdot 7 \mathrm{H}_{2} \mathrm{O} \quad 0.50$; $\mathrm{CaCO}_{3}$ 10). A $10 \mathrm{ml}$ aliquot of the seed culture was added to a $250 \mathrm{ml}$ Erlenmeyer flask containing $50 \mathrm{ml}$ aliquot of the production media and shaken at $220 \mathrm{rpm}$ at $22^{\circ} \mathrm{C}$ for 24 days. Fungal growth in each flask was extracted with $60 \mathrm{ml}$ of methyl ethyl ketone.

A 1 liter fermentation broth of MF6822 was extracted with 1 liter of methyl ethyl ketone (MEK), layers were separated and MEK extract was concentrated under reduced pressure to afford a solid material. Dried MEK extract was dissolved in $50 \mathrm{ml}$ methanol charged on to a 2 liter column of Sephadex LH 20 and eluted with methanol at a flow rate of $10 \mathrm{ml} /$ minute. Active components $\mathbf{2} \sim \mathbf{5}$ eluted in $1.3 \sim 1.5$ column volumes of eluent. These fractions were pooled to give $62 \mathrm{mg}$ of a residue. The residue was dissolved in $1.5 \mathrm{ml}$ methanol and chromatographed on a Zorbax RX $-8 \quad(21 \times 250 \mathrm{~mm})$ column eluting at a flow rate of $8 \mathrm{ml} /$ minute with a 40 minutes gradient of 20 to $90 \%$ aqueous $\mathrm{CH}_{3} \mathrm{CN}$ containing $0.1 \%$ TFA. Fractions eluting in the 15 to 30 minutes range showed activity. The active fractions were analyzed by HPLC, combined into two pools, concentrated under reduced pressure and lyophilized to yield 8 and $3 \mathrm{mg}$ of colorless amorphous powders, respectively.

A one fourth portion of the $3 \mathrm{mg}$ fraction was further purified by HPLC using a Zorbax RX C-8 $(4.6 \times 250 \mathrm{~mm})$ column eluting with $45 \%$ aqueous $\mathrm{CH}_{3} \mathrm{CN}$ containing $0.1 \%$ TFA at a flow rate of $1 \mathrm{ml} /$ minute. The process was repeated four times and fractions eluting at $\mathrm{Rt}=15.12$ and $\mathrm{Rt}=17.15$ minutes were concentrated and lyophilized to give 0.2 and $0.4 \mathrm{mg}$ of emestrin E (4) and emestrin C (2), respectively, as colorless amorphous powders.

A tenth portion of the $8 \mathrm{mg}$ fraction was further purified by HPLC using a YMC diol $(4.6 \times 250 \mathrm{~mm})$ column eluting with a $20 \%$ isopropyl alcohol/hexane at a flow rate of $1 \mathrm{ml} /$ minute and repeated ten times. Fractions eluting at $\mathrm{Rt}=14.13$ and $\mathrm{Rt}=31 \sim 34$ minutes were concentrated under vacuum and lyophilized to yield $1 \mathrm{mg}$ of secoemestrin $\mathrm{C}_{1}(\mathbf{5})$ as a colorless amorphous powder as well as $3 \mathrm{mg}$ of an enriched fraction containing emestrins D (3) and $\mathrm{E}$ (4). The latter fraction was further purified by HPLC on a Zorbax RX C-8 $(4.6 \times 250 \mathrm{~mm})$ column eluting with a $45 \%$ aqueous $\mathrm{CH}_{3} \mathrm{CN}$ containing $0.1 \%$ TFA at a flow rate of $1 \mathrm{ml} /$ minute. Pooled fractions eluting at $\mathrm{Rt}=12.85$ minutes from multiple runs were concentrated and lyophilized to give $1.4 \mathrm{mg}$ of $\mathbf{3}$, and an additional small amount of 4.

Emestrin C (2): RPHPLC Rt $=17.15$ minutes [Zorbax RX C-8 $(4.6 \times 250 \mathrm{~mm}) 45: 55 \mathrm{CH}_{3} \mathrm{CN}-\mathrm{H}_{2} \mathrm{O}+0.1 \%$ TFA, $1 \mathrm{ml} /$ minute $] ;[\alpha]_{\mathrm{D}}^{25}=+75^{\circ}(c 0.16, \mathrm{MeOH}), \mathrm{UV}(\mathrm{MeOH})$ $\lambda_{\max }(\varepsilon) 207$ (26435), 221 (sh), 266 (sh), 283 (sh) nm; IR (ZnSe) $v_{\max } 3464 \mathrm{br}, 2933,1685,1267 \mathrm{~cm}^{-1} ;{ }^{1} \mathrm{H}$ and ${ }^{13} \mathrm{C}$ NMR (see Table 1); LCESIMS $(\mathrm{m} / \mathrm{z}) 1247[2 \mathrm{M}+\mathrm{Na}]^{+}, 531$ [M- $\mathrm{H}_{2} \mathrm{O}-2 \mathrm{~S}$ ]; HRESIFTMS $(\mathrm{m} / \mathrm{z}) 635.0770$ (calcd for $\mathrm{C}_{28} \mathrm{H}_{24} \mathrm{~N}_{2} \mathrm{O}_{10} \mathrm{~S}_{2}+\mathrm{Na}$ 635.0765).

Emestrin D (3): RPHPLC Rt=12.85 minutes [Zorbax RX C-8 $(4.6 \times 250 \mathrm{~mm}), 45: 55 \mathrm{CH}_{3} \mathrm{CN}-\mathrm{H}_{2} \mathrm{O}+0.1 \%$ TFA, $1 \mathrm{ml} /$ minute $] ;[\alpha]_{\mathrm{D}}^{25}=+89.3^{\circ}(c 0.56, \mathrm{MeOH}) ; \mathrm{UV}(\mathrm{MeOH})$ $\lambda_{\max }(\varepsilon) 206$ (76388), 221 (sh), 255 (34352), 286 (sh) nm; IR (ZnSe) $v_{\max } 3443 \mathrm{br}, 2933,1682,1268 \mathrm{~cm}^{-1} ;{ }^{1} \mathrm{H}$ and ${ }^{13} \mathrm{C}$ NMR (see Table 1); LCESIMS $(\mathrm{m} / z) 1306\left[2 \mathrm{M}+\mathrm{NH}_{4}\right]^{+}$; HRESIFTMS (m/z): 667.0493 (calcd for $\mathrm{C}_{28} \mathrm{H}_{24} \mathrm{~N}_{2} \mathrm{O}_{10} \mathrm{~S}_{3}+$ $\mathrm{Na}, 667.0491$ ), 627.0554 (calcd for $\mathrm{C}_{28} \mathrm{H}_{22} \mathrm{~N}_{2} \mathrm{O}_{9} \mathrm{~S}_{3}+\mathrm{H}$, 627.0566), 531.1341 (calcd for $\mathrm{C}_{28} \mathrm{H}_{22} \mathrm{~N}_{2} \mathrm{O}_{9}+\mathrm{H}, 531.1404$ ).

Emestrin E (4): RPHPLC Rt=15.12 minutes [Zorbax RX C-8 (4.6×250 mm), $45: 55 \mathrm{CH}_{3} \mathrm{CN}-\mathrm{H}_{2} \mathrm{O}+0.1 \%$ TFA, $1 \mathrm{ml} /$ minute]; UV (MeOH) $\lambda_{\max }$ ( $(\varepsilon) 205$ (22084), 221 (sh), 
261 (10563), 290 (sh) nm; IR (ZnSe) $v_{\max }$ 3360, 2924, 1686, $1267 \mathrm{~cm}^{-1}$; ${ }^{1} \mathrm{H}$ and ${ }^{13} \mathrm{C}$ NMR (see Table 1); LCESIMS $(m / z) 1370\left[2 \mathrm{M}+\mathrm{NH}_{4}\right]^{+}, 531\left[\mathrm{M}-\mathrm{H}_{2} \mathrm{O}-4 \mathrm{~S}\right]$; HRESIFTMS $(m / z) 699.0202$ (calcd for $\mathrm{C}_{28} \mathrm{H}_{24} \mathrm{~N}_{2} \mathrm{O}_{10} \mathrm{~S}_{4}+$ $\mathrm{Na}, 699.0211)$.

Secoemestrin $\mathrm{C}_{1}$ (5): HPLC Rt=14.13 minutes [YMC diol $(4.6 \times 250 \mathrm{~mm}) 1: 4 i \mathrm{PrOH}$ - hexane, $1 \mathrm{ml} /$ minute]; RPHPLC $\mathrm{Rt}=12.5$ minutes [Zorbax RX C-8 $(4.6 \times 250$ $\mathrm{mm}$ ), 15 minutes $20 \sim 90 \%$ gradient of aqueous $\mathrm{CH}_{3} \mathrm{CN}+$ $0.1 \% \mathrm{TFA}, 1 \mathrm{ml} /$ minute), $[\alpha]_{\mathrm{D}}^{25}=-134.1^{\circ}(c 0.4, \mathrm{MeOH})$, UV (MeOH) $\lambda_{\text {max }}(\varepsilon) 208$ (64901), 221 (sh), 263 (20392), 296 (11030) nm; IR (ZnSe) $v_{\max } 3364$ (br), 2925, 1690, $1291 \mathrm{~cm}^{-1}$; ${ }^{1} \mathrm{H}$ and ${ }^{13} \mathrm{C}$ NMR (see Table 1); LCESIMS $(\mathrm{m} / \mathrm{z}) 556\left[\mathrm{M}+\mathrm{NH}_{4}\right]^{+} ; \operatorname{HRESIFTMS}(\mathrm{m} / \mathrm{z}): 556.1212$ (calcd for $\mathrm{C}_{26} \mathrm{H}_{22} \mathrm{~N}_{2} \mathrm{O}_{7} \mathrm{~S}_{2}+\mathrm{NH}_{4}, 556.1212$ ), 385.0674 (calcd for $\mathrm{C}_{19} \mathrm{H}_{17} \mathrm{~N}_{2} \mathrm{O}_{3} \mathrm{~S}_{2}, 385.0681$ ), 320.1150 (calcd for $\mathrm{C}_{19} \mathrm{H}_{16} \mathrm{~N}_{2} \mathrm{O}_{3}, 320.1161$ ).

\section{Fermentation and Isolation of Chaetomin (6)}

The sterile mycelia of MF6838 was isolated from a soil sample collected in Argentina and inoculated into seed flasks by transferring a $1 \mathrm{ml}$ aliquot of a frozen culture into a $250 \mathrm{ml}$ Erlenmeyer flask containing $50 \mathrm{ml}$ of $\mathrm{KF}$ seed medium (in $\mathrm{g} /$ liter water, corn steep liquor 5; tomato paste 40; oat flour 10; glucose 10; trace elements $10 \mathrm{ml}, \mathrm{pH} 6.8$ ). The seed culture was incubated at $25^{\circ} \mathrm{C}$ on a gyratory shaker (220 rpm) for 4 days before transfer to GG1 production medium (in $\mathrm{g} /$ liter water, glycerol 75 , glucose 10; ardamine $\mathrm{pH} \mathrm{5,}\left(\mathrm{NH}_{4}\right)_{2} \mathrm{SO}_{4} 2$, soybean meal 5, tomato paste 5 , sodium citrate 2). A $10 \mathrm{ml}$ aliquot of the seed culture was added to a $250 \mathrm{ml}$ Erlenmeyer flask containing production media and shaken at $220 \mathrm{rpm}$ for 20 days at $22^{\circ} \mathrm{C}$. Fungal growth in each flask was extracted with $60 \mathrm{ml}$ of methyl ethyl ketone by shaking for 30 minutes.

A $30 \mathrm{ml}$ extract was concentrated under reduced pressure to afford $30 \mathrm{mg}$ semi-solid. This material was dissolved in $1.5 \mathrm{ml}$ methanol and chromatographed on a Zorbax RX C-8 $(21 \times 250 \mathrm{~mm})$ column eluting at a flow rate of $8 \mathrm{ml} /$ minute with a 40 minutes gradient of 30 to $70 \%$ aqueous $\mathrm{CH}_{3} \mathrm{CN}$ containing $0.1 \%$ TFA. Fractions eluting between 34 and 36 minutes were pooled, concentrated under reduced pressure and lyophilized to furnish $2.3 \mathrm{mg}$ of chaetomin (6) as an amorphous powder. $\mathrm{Rt}=5.79$ minutes (Zorbax $\mathrm{RX} \mathrm{C}-8$, $4.6 \times 250 \mathrm{~mm}, \mathrm{CH}_{3} \mathrm{CN}-\mathrm{H}_{2} \mathrm{O}+0.1 \%$ TFA, $1 \mathrm{ml} /$ minute), identified by comparison of UV, ${ }^{1} \mathrm{H}$ and ${ }^{13} \mathrm{C}$ NMR and mass spectral data with an authentic sample [12].

\section{Fermentation and Isolation of Cytochalasins A (7) and B (8)}

Nonsporulating sterile mycelium GB4200 (isolated from decaying leaves of Citharexylum macredenium
(Verbenaceae), Parque Nacional Braulio Carillo, Heredia Province, Costa Rica) were inoculated into seed flasks by transferring a $1 \mathrm{ml}$ aliquot of a frozen culture into a $250 \mathrm{ml}$ Erlenmeyer flask containing $50 \mathrm{ml}$ of YMEJ seed medium (in $\mathrm{g} /$ liter water, yeast extract 4 , malt extract 8 , dextrose 4 , junlon 1.5, $\mathrm{pH} 7.0$ ). The seed culture was incubated at $25^{\circ} \mathrm{C}$ on a gyratory shaker $(220 \mathrm{rpm})$ for 3 days before transfer to NPF2 production medium and conditions as described for production of emestrin.

A $30 \mathrm{ml}$ fermentation was extracted with $36 \mathrm{ml}$ MEK. The extract was concentrated to dryness and chromatographed on a $70 \mathrm{ml}$ Sephadex LH 20 column using $\mathrm{MeOH}$. Concentration of fractions eluting at 0.85 column volume afforded $16 \mathrm{mg}$ of a mixture of cytochalasins. The cytochalasin mixture was chromatographed on RPHPLC (Zorbax RX C-8, $21 \times 250 \mathrm{~mm}$ ) and eluted with a 35 minutes gradient of 40 to $90 \%$ aqueous $\mathrm{CH}_{3} \mathrm{CN}+0.1 \%$ TFA at a flow rate $8 \mathrm{ml} /$ minute. Concentration of fractions eluting at $16 \sim 20$ and $22 \sim 25$ minutes under reduced pressure followed by lyophilization afforded $3.6 \mathrm{mg}$ of cytochalasin B (8) and $1.2 \mathrm{mg}$ of cytochalasin A (7), respectively.

\section{Membrane Binding Assay}

Membranes, prepared from CCR2b-transfected $\mathrm{CHO}$ cells $(2 \mu \mathrm{g})$, were incubated with $25 \mathrm{pM}{ }^{125} \mathrm{I}$-hMCP-1 (2200 $\mathrm{Ci} / \mathrm{mmol}$ ) in buffer containing $50 \mathrm{mM}$ HEPES $\mathrm{pH} 7.4$, $0.5 \%$ BSA, $5 \mathrm{mM} \mathrm{MgCl}_{2}, 1 \mathrm{mM} \quad \mathrm{CaCl}_{2}, 0.1 \mathrm{mg} / \mathrm{ml}$ bacitracin and $0.01 \%$ protease inhibitors cocktail for 1 hour at room temperature. Non-specific binding was measured in the presence of $100 \mathrm{nM}$ unlabeled hMCP-1. Test samples were reconstituted in DMSO and $2 \mu$ were tested in a final volume of $250 \mu \mathrm{l}$. The reaction was terminated by filtration onto GF/B filter plates presoaked with $0.33 \%$ polyethyleneimine using a Tomtec 9600 Cell Harvester. The filters were washed with $25 \mathrm{mM}$ HEPES pH 7.4 containing $0.5 \mathrm{M} \mathrm{NaCl}$ and $0.01 \%$ sodium azide. Subsequently, filter plates were dried and counted for radioactivity in a Topcount NXT after addition of $50 \mu$ l Microscint 0 .

\section{Whole Cell Binding Assay}

Monocytes were harvested from Leukopacks and resuspended to a final density of $2 \times 10^{6}$ cells $/ \mathrm{ml}$ binding buffer. Cells (200000) were incubated with ${ }^{125} \mathrm{I}-\mathrm{hMCP}-1$ $(\sim 25 \mathrm{pM}, 2200 \mathrm{Ci} / \mathrm{mmol})$ at room temperature for 45 minutes in buffer containing HEPES $(50 \mathrm{mM}), \mathrm{MgCl}_{2}$ $(5 \mathrm{mM}), \mathrm{CaCl}_{2}(1 \mathrm{mM})$, BSA $(0.5 \%)$, and protease inhibitor cocktail at $\mathrm{pH}$ 7.4. Reactions were terminated by filtration over GF/B filters that had been presoaked in $0.10 \%$ polyethyleneimine using a Packard Cell Harvester. The filters were washed with HEPES $(25 \mathrm{mM}), \mathrm{pH} 7.5$ 
containing $\mathrm{NaCl}(500 \mathrm{mM})$ and the plates were dried. Plates were counted for ${ }^{125} \mathrm{I}$ radioactivity using Microscint 0 and a Topcount NXT.

\section{References}

1. Ley K. Arrest, migration, survival, and proliferation of leukocytes and vascular cells: The many faces of chemokine biology. Microcirculation 10: 245-246 (2003)

2. Daly C, Rollins BJ. Monocyte chemoattractant protein-1 (CCL2) in inflammatory disease and adaptive immunity: Therapeutic opportunities and controversies. Microcirculation 10: 247-257 (2003)

3. Charo IF, Peters W. Chemokine receptor 2 (CCR2) in atherosclerosis, infectious diseases, and regulation of T-cell proliferation. Microcirculation 10: 259-264 (2003)

4. Rose CE, Jr, Sung SSJ, Fu SM. Significant involvement of CCL2 (MCP1) in inflammatory disorders of the lung. Microcirculation 10: 273-288 (2003)

5. Cascieri MA, Springer MS. The chemokine/chemokinereceptor family: Potential and progress for therapeutic intervention. Curr Opin Chem Biol 4: 420-427 (2000)

6. Gong JH, Ratkay LG, Waterfield JD, Clark-Lewis I. An antagonist of monocyte chemoattractant protein 1 (MCP-1) inhibits arthritis in the MRL-lpr mouse model. J Exp Med 186: 131-137 (1997)

7. Brodmerkel CM, Collins R, Hall L, Hertel D, Stewart R, Wang A, Xue CB, Diamond S, Friedman S, Vaddi K. In 68th Annual Meeting of American College of Rheumatology, San Antonio, Texas, 2004

8. Seya H, Nozawa K, Nakajima S, Kawai K, Udagawa S. Studies on fungal products. Part 8. Isolation of structure of emestrin, a novel antifungal macrocyclic epithiodioxopiperazine from Emericella striata. X-ray molecular structure of emestrin. J Chem Soc Perkin Trans 1 1986: 109-116 (1986)

9. Ooike M, Nozawa K, Kawai KI. An epitetrathiodioxopiperazine related to emestrin from Emericella foveolata. Phytochemistry 46: 123-126 (1997)

10. Nozawa K, Udagawa S, Nakajima S, Kawai K. Studies on fungal products. XIV. Emestrin B, a new epithrithiodioxopiperazine, from Emericella striata. Chem Pharm Bull 35: 3460-3463 (1987)

11. Onodera H, Hasegawa A, Tsumagari N, Nakai R, Ogawa T, Kanda Y. MPC1001 and its analogues: New antitumor agents from fungus Cladorrhinum species. Org Lett 6: 4101-4104 (2004)

12. Cole RJ, Cox RH. Handbook of Toxic Fungal Metabolites. Academic Press, New York, 1981.

13. Ueno $\mathrm{Y}$, Umemori $\mathrm{K}$, Nimi E, Tanuma S, Nagata S, Sugamata M, Ihara T, Sekijima M, Kawai K, Ueno I. Induction of apoptosis by T-2 toxin and other natural toxins in HL-60 humna promyelotic leukemia cells. Nat Toxins 3: 129-137 (1995)

14. Terao K, Ito E, Kawai K, Nozawa K, Udagawa S. Experimental acute poisoning in mice induced by emestrin, a new mycotoxin isolated from Emericella species. Mycopathologia 112: 71-79 (1990)

15. Ishikawa J, Okano J, Ohki K, Amagai A, Maeda Y, Miyata H. Phagocytosis of Dictyostelium discoideum studied by the particle-tracking method. Exp Cell Res 288: 268-276 (2003)

16. von-Wolff M, Ursel S, Hahn U, Steldinger R, Strowitzki T. Glucose transporter protiens (GLUT) in human endometrium: Expression, regulation, and function throughout the menstrual cycle and in early pregnancy. J Clin Endocrinol Metabol 88: 3885-3892 (2003)

17. Wndhaber RAJ, Wilkins RJ, Meredith D. Functional characterization of glucose transport in bovine articular chondrocytes. Pflügers Archiv Eur J Physiol 446: 572-577 (2003)

18. Hagglund CL, Gottschalk I, Lundahl P. Cytochalasin Bbinding and transport properties of the Glut1 human red cell glucose transporter. Recent Res Dev Bioenerget 1: 117-129 (2000)

19. Ondeyka J, Hensens OD, Zink D, Ball R, Lingham RB, Bills G, Dombrowski A, Goetz M. L-696,474, a novel cytochalasin as an inhibitor of HIV-1 protease II. Isolation and structure. J Antibiot 45: 679-685 (1992)

20. Mack M, Kleinschmidt A, Bruhl H, Klier C, Nelson PJ, Cihak J, Plachw J, Stangassinger M, Erfle V, Schlondorff D. Transfer of the chemokine receptor CCR 5 between cells by membrane-derived microparticles: A mechanism for cellular human immunodeficiency virus 1 infection. Nat Med 6: 769-775 (2000)

21. Gribble AD, Forbes IT, Witherington J. Preparation of 3subsituted indoles or fused pyrroles as antagonists of the chemokine MCP-1 (CCR2B) receptor. GlaxoSmithKline, 2002, WO 2002079151 A1.

22. Yang L, Butora G, Parsons WH. Preparation of $N$-cyclopentylpiperidines as modulators of chemokine receptor activity. Merck \& Co., Inc., 2002, WO 2002013824 A1. 